\title{
Research on Plastic Working
}

by

\section{Yoichi TAKAHASHI*}

この度は, 塑性工学部門委員会からのご推薦により， 貴重な執筆の機会を頂きました。本稿では，私の自己紹 介と最近の研究内容について述べさせて頂きます.

私は, 高松工業高等専門学校 (現香川高等専門学校, 以 後高専と略す) を卒業後, 豊橋技術科学大学に編入学し, その後同大学院を修了後すぐに同高専機械工学科に着任 しました，大学では, 精密加工研究室に所属し, 硬脆材 料の研削・研磨, 超精密マザーマシン, MEMS(Micro Electro Mechanical Systems) 等の幅広い研究分野に携わ ることができました. 特に大学院生時代には, MEMS 技術を活用したマイクロインプリントに関す研究を行 いました。これは， $\mu \mathrm{m}$ オーダーの微細な凹凸を有す る金型形状を熱可塑性樹脂 (Polymethyl Methacrylate : PMMA) に転写させるものです。金型を使ってPMMA を塑性変形させるということから, 塑性加工に携わる きっかけになる研究だったと思います。

本格的に塑性加工の研究に従事するようになったの は，高専に着任してからになります。ここでは，スピ ニング加工を用いたステンレス鋼管の口絞り成形に関 する研究 ${ }^{1)}$ について紹介します。塑性加工の代表的加工 法といえば，鍛造やプレスが思い浮かびますが，スピ ニング加工は回転塑性加工に分類され, 回転させた素 材に工具を押し当て, 局所的な塑性変形を徐々に繰り 返し与えて全体の製品形状を創成する加工方法になり ます。加工の一例として, 自動車用触媒ケースを対象 としたフェライト系ステンレス鋼管 (SUS409) の口絞り 成形の模式図を図 1 に示します. 図1のように2つのロー ラーが固定された鋼管の周りを螺旋運動しながら軸方 向と半径方向に移動することによって徐々に管端部が 絞られます。図 2 に成形後の素材の形状を示します。本 加工では, 外径 $120 \mathrm{~mm}$, 肉厚 $1.5 \mathrm{~mm}$ のSUS409の管端 を外径 $54 \mathrm{~mm}$ まで絞っています。図2(a)では, 実験及び

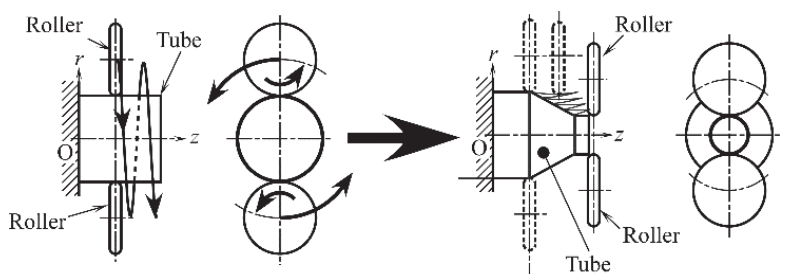

図1. 成形の模式図
シミュレーション共に良好に成形できていますが, 加 工条件が悪いと, 図2(b)のようにしわ等の加工欠陥が 発生します。図1に示した成形の模式図からも分かるよ うに素材は，ローラーに接触していない自由表面領域 が広く，その変形機構は複雑です。また，成形条件因 子も多く, 加工欠陥に対して適切な加工条件を見出す ことが難しいといった課題もあります。これまでに, 素材とローラーの総接触回数を多くすることで縮径部 の寸法精度が向上することを明らかにしています.

最後になりますが, 高専に着任して早いもので 14 年 が経過しました，近年，高専の使命はグローバルに活 躍できる実践的かつ創造的な技術者育成であるとされ ています。塑性加工の研究を通して, 微力ながら学生 の技術者教育に貢献できればと思います。

\section{参考文献}

1) Y. Takahashi, S. Kihara, T. Nagamachi, H. Mizumoto, Y. Nakata, "Effects of Forming Conditions on Wrinkling in Necking of Tube End", Materials Transactions, Vol. 52, No. 1, pp. 31-36(2011).

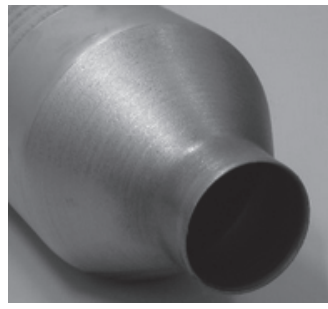

実験

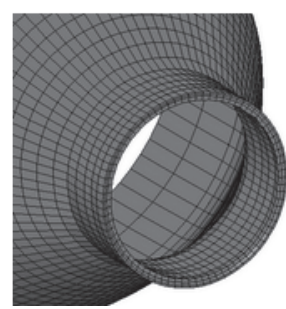

シミュレーション

(a)成形成功

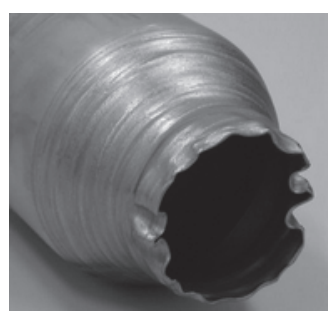

実験

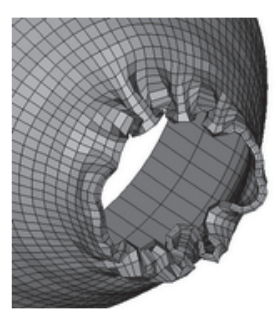

シミュレーション (b)加工欠陥の発生

図 2. 成形形状

† 原稿受理 令和元年 10 月 30 日 Received Oct. 30, 2019 C2020 The Society of Materials Science, Japan

* 香川高等専門学校械工学科 ₹ 761-8058 高松市勅使町, Dept. of Mech. Eng., National Ins. of Tech. (KOSEN), Kagawa College, Chokushi-cho, Takamatsu, 761-8058 